\title{
A Compreensão de Hegel da Modernidade
}

Max de Filippis Resende ${ }^{1}$

Para a compreensão do pensamento histórico hegeliano da modernidade é preciso ter em vista o seu princípio da "liberdade subjetiva”. É ele que assinala, para o filósofo, a essencialidade dessa época e o que faz parte do desdobramento do "espírito" em seu progresso, a história universal, no esforço de chegar à consciência de que é em si mesmo, de que é livre, por que é por si mesmo. A história universal estaria no campo espiritual, quer dizer, daquilo que é mais propriamente humano, o próprio espiritual, e tudo é apenas em relação ao espírito, à essencialidade do humano, sendo na história que o espírito alcança sua realidade mais concreta, ou seja, realiza-se.

É apenas na Idade Moderna que a vontade do sujeito será encarada em termos de sua total autonomia, têm-se a consciência de que a subjetividade do indivíduo pertence apenas a ele, e de que ele pode usá-la livremente. Com isso, acredita-se que os homens, para seus atos, podem basear-se apenas em suas próprias convicções, em sua racionalidade. Esta convicção deste pensar independente, e esta ação como seu produto, estariam em plena comunhão com o agir do "espírito absoluto”, a essência racional de toda realidade, pois, como este, é o que é por si mesmo. Ou seja, livre, pois está em si mesmo, na “atividade de voltar-se para si e assim se produzir, fazer o que ele é em si”"2. Para Hegel, a substância do espírito, sua essência, é a liberdade, e todas as suas propriedades são mediante a liberdade. A ação do espírito se dá no âmbito de uma universalidade viva, a identidade de um povo, sua cultura em geral, que constitui uma substância única, um espírito, que penetra na consciência do indivíduo. Nos "novos tempos”, o indivíduo, com a consciência de que é livre, exige agora a sua particularidade: opinião, querer e consciência próprios.

A aplicação do princípio de liberdade às coisas do mundo, faria parte, então, do longo processo que constitui a própria história. A idéia de liberdade, o seu conceito, sai de si mesma, sua essência, para produzir-se na história. Produz, assim, uma realidade histórica, ética, social e política do espírito humano através de relações de igualdade e diferença da idéia de liberdade, em sua efetividade enquanto desenrolar de um momento da manifestação do espírito na história. Processo este que, para Hegel, culminaria no Estado Moderno, sendo ele a representação histórica da "Idéia de liberdade”, que ao se relacionar com o indivíduo, representação da liberdade enquanto subjetividade, moveria o processo dialético da história.

A subjetividade afloraria nos tempos modernos como uma exigência histórica, e distinguiria muito bem a modernidade das outras épocas históricas. É a liberdade subjetiva que "se constitui em fato histórico concreto apenas na modernidade ao configurar-se na exterioridade jurídica da pessoa e da propriedade e ao efetivar-se na interioridade de uma subjetividade moral que tem em si mesma, na sua consciência, o critério do agir livre". ${ }^{3}$ Isso seria também uma particularidade do mundo cristão ocidental, pois no Oriente apenas um homem seria livre, o déspota; e a lei moral não viria do saber do próprio homem, seria algo que exerce coerção sobre ele. Na Grécia Antiga o espírito animaria o indivíduo a estar em uma harmonia, uma vida ética, onde o fim do indivíduo e o fim do Estado coincidiriam. O cidadão era membro de uma totalidade, a pólis, obedecendo não a uma consciência moral vinda da sua subjetividade, mas a costumes objetivos da pólis. A satisfação das vontades também diz respeito à pólis e não ao querer do indivíduo, as particularidades são ignoradas. E justamente o que teria rompido com essa eticidade seria a "infinitude da consciência de si mesmo", que estaria contida, na análise hegeliana, tanto nos sofistas quanto no pensamento de Sócrates. Hegel também vê uma pequena manifestação deste princípio no direito romano, quando o homem adquire a individualidade jurídica.

Mas é só com o cristianismo que o homem adquiriria uma interioridade individual, e é na sua subjetividade que ele manifestaria sua liberdade. No cristianismo o indivíduo enriqueceria-se e se salvaria na interiorização da pessoa, consagrando o "valor infinito do indivíduo”. A partir dessa noção é que se efetivaria a realização da liberdade subjetiva, cujo momento decisivo, para Hegel, será a Reforma Protestante, pois não valorizará as relações externas e materiais da religiosidade, despertando no homem uma consciência moral que ganha certeza de si na intimidade da fé e no contato direto com Deus.

Além da Reforma, como exigência do espírito da modernidade, o Iluminismo surgiria como pensamento onde a explicação da realidade se dá pela razão. A reflexão subjetiva é autoridade agora, e a Revolução Industrial Inglesa também contribui para esse quadro, lançando as bases de uma nova economia, onde a força de trabalho do indivíduo torna-se autônoma e adquire valor de mercado. Mas o ponto decisivo do desdobramento do espírito da modernidade seria a Revolução Francesa, pois é com ela que o princípio da liberdade efetivaria-se politicamente. Hegel constata que é aí que o homem torna-se universal, pois a liberdade seria declarada como direito. A razão é estabelecida no mundo dos acontecimentos históricos. Apesar desta constatação, Hegel assinala um fracasso da

\footnotetext{
${ }^{1}$ Graduando Filosofia UFPR

${ }^{2}$ HEGEL, G. W. F.. Filosofia da História. Brasília: Editora Universidade de Brasília, p. 24.

${ }^{3}$ RAMOS, César A.. Liberdade Subjetiva e Estado na Filosofia Política de Hegel. Curitiba: Ed. Da UFPR, 2000. p. 26.

${ }^{4}$ Idem, p. 29
} 
Revolução, visto que esta assumiu um caráter "anárquico”. No desejo de liberdade desenfreado, quis-se efetivar os ideais revolucionários através do terror, com a violência contra as instituições políticas, não sendo solidificado o princípio da liberdade politicamente através das mesmas.

Na Reforma, Hegel assinala a decadência da Igreja Católica visto que esta não participava da atividade do espírito pois passava a considerar o exterior como algo em si, e por isso o divino passa a ser considerado algo finito. No luteranismo seria resgatado o ensinamento de Cristo, que passaria a estar presente na fé e no espírito. Assim, a verdade passa a estar ao alcance de todos, e não só nas mãos de uma classe privilegiada. O indivíduo está, então, plenificado e torna-se um espírito livre, determinado por si mesmo. A partir daí as instituições sociais devem então basear-se na livre vontade. A interioridade gera a universalidade do pensamento, onde a razão é o fundamento substancial tanto da consciência como do exterior e do natural, e, com isso, a experiência torna-se a ciência do mundo. A autoridade religiosa é substituída pelo pensar do sujeito por si mesmo, e florescem as ciências naturais e as determinações universais através do Iluminismo. Também a liberdade da vontade passa a ser exigida, mas defrontava-se com a religião. Na Reforma a Igreja protestante tem de lutar por uma existência política, assegurando para si posses materiais, como propriedades políticas e particulares tomadas da Igreja Católica. Na Alemanha, o Iluminismo estava ao lado da teologia, mas na França voltou-se contra a Igreja, e a mudança foi necessariamente violenta. A vontade, que é apenas um conceito formal, veio à tona no movimento desenfreado das paixões. Governo e constituição foram destruídos e reinou o princípio abstrato da liberdade, e também seu terror. Os franceses quiseram executar na pátria a idéia de liberdade, que para os alemães teria permanecido no âmbito formal. Isto por que surge do pensamento abstrato, do entendimento, e defrontou-se com a religião, conteúdo concreto absoluto. A existência do homem passa, assim, a centrar-se no pensamento, que passaria a governar a realidade espiritual. É permitido ao homem usufruir livremente de suas forças, e no âmbito político, ter livre acesso às instituições estatais. Mas, Hegel alerta que não haveria constituição sensata com a religião católica, visto que o governo e o povo precisariam garantir entre si uma igualdade de vontade interna, possível apenas numa religião que leve em consideração a racionalidade, expressão da liberdade subjetiva. Por isso, passaria a reinar na França, depois da derrubada de todas as instituições, apenas a desconfiança e a suspeita. O poder é exercido sem formas judiciais, predominando como punição a morte. A única forma de segurança vem com Napoleão, que a estabelece com a força militar, por vontade individual, em que, então, resume-se o Estado, ou seja, respeito e medo. Uma mão de ferro controla tudo e abafa a confusão imperiosamente, para ir como veio, de repente, dando lugar a uma monarquia constitucional.

A história universal seria este desenvolvimento do conceito de liberdade, mas a liberdade real exigiria, portanto, a submissão da vontade formal. A filosofia, para Hegel, tem de conhecer o processo de desenvolvimento dessa verdadeira idéia, que é a idéia da liberdade, enquanto consciência da liberdade. Neste desenrolar do espírito da modernidade Hegel sente a necessidade de um esforço da filosofia em conquistar reconhecimento frente à preocupação por interesses práticos ordinários. A filosofia deveria aliar-se ao interesse pelos grandes acontecimentos históricos de alcance universal, e, com a consolidação do Estado moderno, poderia florescer uma ciência pura do espírito, sendo que: "Como atividade humana de pensar concretamente, a filosofia constitui, para Hegel, um processo autônomo e produtivo que estabelece aquela totalidade verdadeira transformando poderosamente todos os conteúdos que incorpora.”.

A filosofia, como pensamento conceitual, que conhece a si mesmo tendo consciência de que sabe, portanto pensamento ideal, converteria outras esferas de modos de pensamento em conhecimento de si, quando por estas passa seu olhar. Transforma seus saberes em conceito, superando suas dificuldades. Pois seria a filosofia o produto final da atividade livre da razão universal, que é , em Hegel, o princípio dominante de um mundo histórico, o mundo moderno, onde o pensamento que pensa a si mesmo é sua expressão. Este mundo moderno é o da era cristã, principalmente efetivado na Reforma Protestante. A preocupação de Hegel com o mundo moderno é de que esta é a era do cristianismo e a verdade revelada neste está muito próxima daquela que a filosofia deve pensar, um desdobramento daquela verdade. A figura de Cristo marca profundamente a história do mundo; Deus faz-se homem, e o homem retorna à unidade, pois todos são filhos de Deus e iguais entre si, humanos e divinos ao mesmo tempo, o homem é livre. Aí tem começo o princípio da subjetividade, pois nela reside a liberdade, nela o sujeito é livre para si, adquirindo valor infinito. Na relação consigo mesmo ele se autoproduz, possui consciência de si e quer a si mesmo; nega e conhece o outro, volta sobre si e determina-se pela negação. É uma relação infinita consigo mesmo. E no processo de tomar consciência de si na história, o espírito exige a efetivação destes princípios, através de instituições sociais. "O presente histórico e o grau de desenvolvimento da humanidade têm a grande forma do espírito universal, a subjetividade.”.

A subjetividade é a essência do que é moderno, passando primeiro da subjetividade pessoal à humanidade espiritual do homem, sendo a subjetividade que opera como princípio histórico decisivo na teoria da modernidade. A subjetividade seria, em Hegel, a força impessoal da Idéia, o espírito absoluto, que contém a essência de todas as coisas. Isto também se daria analogamente no sujeito individual, que tendo uma atividade em

\footnotetext{
${ }^{5}$ CORDUA, C.. El Mundo Ético. Anthropos, Editorial del Hombre. p. 126.

${ }^{6}$ Idem, p. 142.
} 
si mesmo, dirige-se para um outro que seria a sua universalidade, e a alcança enquanto ser pensante que introduz em si as determinações dos objetos pensados, mas, é diferente e independente deles. Este indivíduo dotado de subjetividade divide, nega e unifica a idéia. O espírito absoluto projetando-se em si mesmo torna-se outro para si e se reconhece neste outro, e, portanto, não muda, é sempre o mesmo retirando-se de um outro para si mesmo. A realidade permanece a cada vez, tem sua permanência no voltar-se para si como outro que é sempre o mesmo de novo. Forma-se dessa maneira o mundo no qual a idéia absoluta se reconhece e alcança sua liberdade reconhecendo-se em si mesma, na existência histórica que é sua exterioridade e manifestação. A subjetividade de um mundo histórico seria a relação da idéia absoluta consigo mesma em sua existência como mundo ético instalado em uma natureza conhecida, “a universalidade determinada da idéia por ela mesma. Finalmente, subjetividade é sinônimo de subjetivismo"7.

Para Hegel, haveria uma clara antecipação religiosa de concepção da verdade frente a filosofia, mas o cristianismo conceberia-a insuficientemente, visto que trata Deus e o homem, ou Deus e o mundo, como dois entes finitos que se relacionam. Somente o conhecimento conceitual do princípio da subjetividade conceberia a verdade completa do mesmo, ou, o que é por si mesmo, e por isso o conceito filosófico apropriar-se-ia do conteúdo de seus antecessores. "Porque o conceito é mais rico e posterior representa a verdade do que é”, a liberdade subjetiva do espírito, sua racionalidade absoluta.

Contudo a posteridade indagar-se-ia a respeito do legado hegeliano e desse suposto desenvolvimento do espírito humano, ao longo da história universal, rumo a uma "paz perpétua” de uma sociedade “cosmopolita”, já idealizadas por Kant. Temos, por exemplo, a figura de Schopenhauer, que apenas acusaria Hegel de ser um mau cristão, visto que este se mundanizaria ao enxergar na história a redenção do espírito, pois, assim, renunciaria ao supremo imutável pensando poder realizá-lo na imperfeita ordem mutável do mundo, ao invés de desprezar a ordem terrestre e buscar uma outra existência mais perfeita. Mas podemos citar também Marx, que denunciaria a condição de atomização do indivíduo como detentor de sua força de trabalho autônoma, e questionaria, frente a essa situação, a relação deste com o modo de produção da sociedade moderna capitalista, que, devido ao seu esquematismo conceitual, acabaria por instrumentalizar todas as relações interpessoais, tornando-as não só mecânicas, mas no mecanismo de configuração e perpetuação dessa mecanicidade. No exercício característico do modo de vida moderno, a troca, o indivíduo acabaria por se alienar, ao ter de quantificar a sua força de trabalho contida no produto deste, a mercadoria, que passa a ter vida própria, pois passa a ser dotada das características racionais quantificadas daquele que a criou, e, portanto, a representá-lo na sua relação com outra mercadoria, produto do trabalho de outrem, também alienado por este processo. As relações modernas são relações de troca, e por isso têm fórmula e resultado certo, são determinadas pelas mercadorias que as automatizam e alienam, assim, o sujeito, tornando-o coisa supérflua, simples objeto que serve de meio para a troca, e não mais a consciência de si. Além do fato de o sujeito também tornar-se mercadoria, pois aliena todo o resto de suas características individuais para poder vender a sua força de trabalho, que não é considerada, ao menos, em sua potencialidade, mas como força de trabalho quantificada. E é ela que representa o indivíduo na sociedade, passa a ser o seu ser social, aquilo que ele é para os outros, ou seja, um objeto, mercadoria à venda.

Esta consciência de si e racionalidade do real teriam, ainda, um outro significado para Nietzsche, quer dizer, um outro valor. A própria historicidade racional seria apenas um acúmulo de informação que soterraria a cultura universal, diluindo-a num estilo "filisteu” de "barbárie culta”. Como este homem moderno, o filisteu, não tem cultura, pretende reconhecer-se em todo canto, e com o seu culto da própria imagem, alega ser a realidade seu espelho, não havendo nada mais do que ele próprio, espírito absoluto, racionalidade decifrada do mundo. Assim, este novo tipo de homem que chega ao poder proclama a procura clássica terminada, o "belo" foi atingido na sua figura, ou melhor, representação. Por isso, não é preciso e nem se deve ir além, aos clássicos dedicam-se apenas estátuas, e a cultura deve ser divertimento. Quando pretende-se séria é por motivo de doença e desequilíbrio racional. Afinal de contas não é razoável interferir nos lucros e alterar os hábitos da banal quotidianidade dos jornais, a indiferente passagem dos acontecimentos históricos pelo tempo. Mas como a vida não é apenas racionalidade, mas sim, e sobretudo, sentimento e vontade, de onde inclusive essa pode emergir, não tardam a aparecerem espíritos valorosos, ou melhor, vontades fortes e determinadas que retomam o sentimento clássico da procura, da profundidade, e da já perdida potência e fecundidade da criação humana. Naturezas estas cansadas da uniformidade normativa filistéia, da sua medianidade racional acessível e imposta a todos, a sua mediocrização e impotencionalidade da alma humana em troca da garantia de um bem estar social sem riscos. Mas sem riscos é que não se vive a vida, e a história deve estar a serviço desta e não de seu enfraquecimento, sua “mortificação” por uma inércia inerente a essa quotidianidade filistéia. Por isso a história necessariamente configura-se como ação, pois é ela a parte da própria vida na qual se dá a vida do homem, é o realizar-se desta, e, portanto, de toda realidade. É preciso fazer história sem esquecer-se de viver, e não ser atropelado pelo passado. Para isso deve-se compreender que toda ação exige esquecimento, pois é preciso que se trace um horizonte determinado da história e daquilo que somos, ou seja, um limite, do qual algo fica de fora. O que está dentro é todo o valor que o homem

\footnotetext{
${ }^{7}$ Idem, p.149.

${ }^{8}$ Hegel, citado em : CORDUA, C.. El Mundo Ético. Anthropos, Editorial del Hombre. p. 155.
} 
dá para a sua vida, assim concebendo-a historicamente, determinando-se. Já o que está de fora não lhe interessa, justamente para poder realizar aquilo que interessa, a sua própria história, que, ou seja, é essa vontade da própria vida que se manifesta como interesse no homem para a sua própria concepção, enquanto realidade.

Já em Heidegger, podemos assinalar a crítica de uma falta, nesta tradição da metafísica do ocidente, de uma determinação do conceito de ser, que permanece obscurecido por essa compreensão do homem e da realidade como racionais. Pois esta categorização do pensamento moderno permanece, apesar de toda a sua catalogação do real, por deixar o ser indeterminado. O espírito absoluto, subjetividade do sujeito, ou a racionalidade do real, apesar de ser a essência de tudo que é, quanto a essa verdade de seu ser, não é algo que possa ser apreendido pelo conceito que se pretende absoluto, não pode ser determinado quanto à sua própria essencialidade. Permanece apenas como origem de todo conceito, mas sem a própria originariedade investigada. Por isso é que sem haver um ser próprio determinado o homem ocidental permanece num esquecimento deste e à procura de identidade nos modos possíveis de seu ser-em-um-mundo como ser que aí é. Ser este que, no mundo moderno, sem algo próprio dilui-se na opinião do que é público e tenta reconhecer-se na racionalização dos instrumentos de seu mundocircundante, e, assim, destina-se cada vez mais no seu próprio esquecimento, pois não se pergunta, justamente, por quê abertura e irrupção fundante de mundo é essa que ele mesmo é. O destino próprio do ocidente estaria, portanto, marcado por esta história do esquecimento do ser e por seu envio e aparecimento nas épocas históricas de sua própria concepção, que seriam as suas concepções de mundo através dos homens e da compreensão destes de seu próprio ser. Ou seja, tudo aquilo que é e há, é o próprio ser aparecendo, constituindo-se e destinando-se como compreensão de si mesmo no homem, que é o seu lugar próprio de abertura para si, a própria abertura e disposição de si em compreensão daquilo que é, que é ser sendo si mesmo. 